\title{
Promoting Ethical Behaviours in Nigerian Public Universities: The Effect of Psychological Ownership
}

\author{
ALIYU, Mustapha Olanrewaju ${ }^{1}$ and ISIAKA, Sulu Babaita ${ }^{2}$ \\ ${ }^{1}$ Department of Industrial Relations and Personnel Management, Faculty of \\ Management Sciences, University of Ilorin, Nigeria \\ ${ }^{2}$ Department of Business Administration, Faculty of Management Sciences, \\ University of Ilorin, Nigeria \\ 1ªliyu.om@unilorin.edu.ng, ${ }^{2}$ sibyaka@yahoo.com
}

\begin{abstract}
Due to an outrageous involvement in unethical behavior in industrial organizations, many organizations have started to realize that management must work to fulfil their moral obligations to society in which they operate. The study examines the influence of psychological ownership on the ethical behavior of academic staff in public universities. Extant literature was reviewed from the current development of the construct variables. The survey research method was employed; the population consists of all academic staff working in selected federal universities in Nigeria. Both primary and secondary data were employed. Upon completion of data collection, a combination of both descriptive and inferential statistics was employed as methods of data analysis, the model of this study was tested using the hierarchical regression and correlation analysis. The study found that the correlation coefficients of all dimensions of psychological ownership such as employee' self-efficacy $(\mathrm{R} 2=0.668)$ and employee's sense of belonging (-0.821) were weak-positive related to individual and benevolent ethical behavior. This implies all dimensions have inverse relationship with individual and benevolent ethical behavior and that the increase in each of the dimension of psychological ownership (such as employee's self-efficacy, employee sense of belonging) which decrease the individual and benevolent ethical behavior while the decrease in psychological ownership dimensions will increase individual and benevolent ethical behavior at 5\% level of significant. The study concludes that employees having a sense of ownership with the organization are less likely to deviate from work norms and values. The study, therefore, recommends that in order to minimize unethical behavior within the workplace, the university system must adapt to a specific ethical standard that is centered on extremely important ethical core values in order to resolve the problems associated with negative workplace unethical behaviors.
\end{abstract}

Keywords: Psychological Ownership, Ethical and Unethical Behaviour, Deviant Workplace Behaviour, Organizational Citizenship Behaviour, Public Universities

\section{Introduction}

For decades, academics from various disciplines such as geography, philosophy, sociology, early child development, psychology, human resource development has provided an extensive literature in the organizational ethics and ethical behaviours. The antecedent's development of ethical lapses at companies such as Enron, WorldCom, and Tyco illustrates what can occur as the result of an informal 
unethical culture created by top management (Vardi \& Weitz 2013). The ethical scandals though not limited to the United States but also been prominent across the globe, for instance, Fombrun and Foss (2004) reported that in Europe, companies such as Vivendi (France), Ahold (The Netherlands), Parmalat (Italy), Yukos (Russia), Credit-Suisse (Switzerland), and Shell (Netherlands) have experienced one or two ethical scandals. These unethical behaviours have also been reported in some public universities in Nigerian for instance, Oke, Okunola, Oni, and Adetoro (2010) expressed concern over increasing the nonchalant attitude of lecturers in carrying out their duties. Some of these attitudes include habitual late coming; frequent absence from school without good reasons; refusal to teach students even when on the ground; dodging classes and so on which is led to halfbaked graduates (The Scholar, 2011).

Because of business scandals involving in unethical behaviour, organizations have started to realize that organizational leaders must work to fulfil their moral obligations to the society in which they operate specifically the stakeholders such as consumers, suppliers, employees, local government communities among others (Mendonca, 2001). Unethical behaviour involves, leaving organisation earlier before, taking excessive breaks, sabotaging equipment, lying about hours worked, gossiping about co-workers, sexual harassment, verbal abuse, among others (Anyim, Obisi \& Aliyu, 2018). Unethical behaviours in the workplace has been described by different researchers using a wide variety of terms as follows: (1) antisocial behaviour (Robinson \& O'Leary-Kelly, 1998); (2) organizational resistance (Lawrence \& Robinson, 2017); (3) employee misconduct (Kidder, 2015); (4) workplace retaliation (Skarlicki \& Folger, 1997); (5) dysfunctional behaviour (Choi, Dixon \& Jung, 2014); (6) dysfunctional behaviour and organizational misbehaviour (Vardi \& Weitz 2013); and (7) service dysfunction (Harris \& Ogbonna, 2006). Bennett and Robinson (2003) see ethical behaviour as organizational norms as expectations defined by basic moral standards, traditional community standards, and formal and informal regulatory policies and rules.

The concept of psychological ownership has become a growing concern among the academic and practitioners as a potentially significant predictor of individual attitudes and behaviour. In later work of Pierce, Kostova \& Dirks (2001, 2003), drawing work from sociology, psychology, philosophy and human resource management, formally introduced a theory of psychological ownership in organisations, which sees it as separate and distinct from legal/equity ownership of the organization but a sense of possession which is a psychologically experienced phenomenon where an individual develops possessive feelings for an organization (Hou, Hsu \& Wu, 2009; Mustapha, Martin \& Hughes, 2016). There are multiple ways to think about the ethical context of an organization. The most of the empirical research in this area focused on what is referred to as ethical climate (Victor \& Cullen, 1988; Trevino, Butterfield, \& Mcabe, 1998) or ethical culture (Trevino, Brown \& Hartman 2003), both of which refer to characteristics of the organization that do or do not support ethics-related attitudes and behaviours 
Because of the inconsistencies from previous studies, some gaps exist for future studies to fill in. First and foremost, previous studies did not exhaust test of psychological ownership and employees' ethical behaviour specifically in the areas of organizational citizenship behaviour and deviant workplace behaviour model across all cultures (Mustapha et al., 2016; Samaila, 2015). Hence, this study aims at just achieving that by testing the model within the Nigerian context. Secondly, literature revealed that no single study has examined the effects of the psychological ownership in promoting ethical behaviours of academic staff in Nigeria except few studies on ethical climate, ethical culture, etc. Meanwhile, several issues about the connection of psychological ownership and promoting ethical behaviours remain unexplored specifically in Nigerian higher institutions.

The present study is an attempt to bridge these theoretical gaps. Therefore, the study examines psychological ownership and how it could be measured since it is associated with positive and negative behavioural and social-psychological consequences.

\section{Research Objectives}

i. To examine the effect of employee self-efficacy on individual ethical behaviour in the selected Nigerian public universities.

ii. To explore the effect of employee sense of belonging on the benevolent ethical behaviour of employees in selected Nigerian public universities.

\section{Literature Review}

\section{Psychological Ownership}

Psychology of ownership is a sense of possession i.e. the feeling that an object, idea, or entity is "mine" or "ours". Various scholars from psychologists, anthropologists, philosophers, geographers, human resources and child development specialists, among others, have explored the psychological aspects of ownership in a variety of contexts, including child development (Isaacs, 1933), consumer behaviour (Bernstein, 1979), house ownership (Porteous, 1976), across different socio-economic strata (Rochberg-Halton, 1984), within the philosophical discussions of being (Sartre, 1969) and in the workplace (Pierce, et al., 2001; Pratt \& Dutton, 2000; Sternberg, 2001).

They unanimously agreed that possession and feelings of ownership are a natural part of the human condition. Pierce, Rubenfield, and Morgan (1991) defined formal ownership in terms of three basic rights, each of which may be present in a specific employee ownership milieu. The rights often associated with ownership are: (1) the right to possession of some portion of the owned object's real being and/or financial value; (2) the right to influence control over the owned object; and (3) the right to information about the position of that which is owned.

\section{Forms of Psychological Ownership}

Avey, Avolio Crossley, and Luthans (2009) divided psychological ownership into promotion-focused and preventionbased forms. According to them, the promotion-focused individuals tend to be goal-oriented, whereas those who are 
prevention-based tend to do what is

needed to avoid punishment.

Table 1: Promotion-Orientated and Prevention-Orientated Focus

\begin{tabular}{|c|c|}
\hline Promotion-orientated focus & Prevention-orientated focus \\
\hline $\begin{array}{l}\text { Employees are sensitive to the } \\
\text { presence/absence of rewards } \\
\text { Concerned with accomplishments and } \\
\text { aspirations } \\
\text { Use an approach as a goal-attainment } \\
\text { strategy } \\
\text { Experience emotions ranging from } \\
\text { elation and happiness to dejection } \\
\text { Associated with a risk bias } \\
\text { More open to change - approach } \\
\text { change as a potential advancement } \\
\text { More creative in problem-solving } \\
\text { processes }\end{array}$ & $\begin{array}{l}\text { Employees are sensitive to the } \\
\text { presence/absence of punishments } \\
\text { Concerned with duties and obligations } \\
\text { Use avoidance as a goal-attainment } \\
\text { strategy } \\
\text { Experience emotions ranging from anxiety } \\
\text { to calmness } \\
\text { Associated with a conservative bias } \\
\text { Less open to change (stick with the } \\
\text { already-known) - follow an avoidance or } \\
\text { conservative strategy }\end{array}$ \\
\hline $\begin{array}{l}\text { Include: } \\
\text { Wishes } \\
\text { Hopes } \\
\text { Aspirations } \\
\text { Represent the "ideal self" }\end{array}$ & $\begin{array}{l}\text { Include: } \\
\text { Obligations } \\
\text { Duties } \\
\text { Responsibilities } \\
\text { Represent the "ought self" }\end{array}$ \\
\hline $\begin{array}{l}\text { Needed to pursue development and } \\
\text { change and to explore the advantage } \\
\text { of creative behaviours }\end{array}$ & $\begin{array}{l}\text { Needed where employees seek to ensure } \\
\text { safety, stability, and predictability }\end{array}$ \\
\hline
\end{tabular}

Source: Kark and Van Dijk (2007) and Liberman, Idson, Camacho, and Higgens (1999); Liberman, Idson, Camacho \& Higgins (1999).

\section{Mixed Effects of Psychological Ownership}

Usually, the outcomes of psychological ownership results in either citizenship or deviant behaviours (VandeWalle, VanDyne \& Kostova 1995; Trevino \& Nelson 2007; Pierce, ODriscoll \& Coghlan 2004), for instance, greater commitment to the organisation (VandeWalle et al., 1995), greater accountability (VandeWalle et al.), greater job satisfaction (Avey et al., 2009; Buchko, 1993; Mayhew, et al., 2007; Pierce et al., 1991; VandeWalle et al.; Van Dyne \& Pierce, 2004), better organisational performance (Van Dyne \& Pierce; Wagner et al., 2003), better organization-based self-esteem (Avey et al. ; Vande-Walle et al.; Van Dyne \& Pierce) more effort on the part of the 
individual to engage in organisational citizenship behaviours (Avey et al. ; Vande-Walle et al.; Van Dyne \& Pierce), increase in extra-role behaviour (Vande-Walle, et al. 1995), meaning that individuals with higher levels of psychological ownership are more likely to engage in extra-role behaviour (constructive work efforts that benefit the organisation and go beyond the required work activities); intention to stay in the organisation ( Avey et al., 2009).

Scholars (e.g., Dirks, Cummings \& Pierce, 1996; Kostova, 1998; Pierce et al., 2001) have further discussed the causal relationship between psychological ownership and willingness to take personal risks and make personal sacrifices. Unfortunately, psychological ownership may lead to other dysfunctional organisational behaviours. Deviant behaviours are another possible outcome of psychological ownership that will lead to violation of organisational norms. However, according to Pierce et al. (2003) psychological ownership will not necessarily lead to dysfunctional effects, but it may lead to the impacts if certain conditions are in place

\section{Ethical Context in the Organization}

There are multiple ways to think about the ethical context of an organization, most of the empirical research in this area focused on what is referred to as ethical climate (Victor \& Cullen, 1988; Trevino, Butterfield, \& Mcabe, 1998) or ethical culture (Trevino, Brown \& Hartman 2003), both of which refer to characteristics of the organization that do or do not support ethics-related attitudes and behaviours (Trevino, Weaver, Gibson, Toffler, 1999). The ethical climate has been defined as the prevailing perceptions of typical organizational practices and procedures that have ethical content or those aspects of work climate that determine what constitutes ethical behaviour at work (Victor \& Cullen, 1988).

Victor \& Cullen (1988) in Samaila (2015) proposed nine types of ethical climate based upon three philosophical approaches (principle, benevolence, and egoism) and three levels of analysis (individual, local, cosmopolitan). They hypothesized that each climate type was associated with specific normative expectations. Subsequent research has found support for some, but not all, of the climate dimensions and their relationships with outcomes. For example, Brown and Trevino (2006); Appelbaum, Deguire, and Lay (2017) found a link between employees' perceptions of a benevolent ethical climate and organizational commitment. Other research has shown that ethical climate dimensions can positively influence managers' ethical decision-making intentions (Flannery \& May 2000 in Leung, 2008) and that ethical climate dimensions are negatively related to willingness to lie (Ross \& Robertson, 2000 in Vardi \& Weitz 2013).

Trevino (1986) proposed ethical culture as a subset or slice of the organization's overall culture that can moderate the relationship between an individual's moral reasoning level and ethical/unethical behaviour. She argued that individuals at higher levels of moral reasoning (principled 
individuals) should be less susceptible to influences from the organizational culture. Trevino (Trevino, 1990; Trevino \& Nelson, 2007) later defined ethical culture in terms of the formal and informal behavioural control systems (e.g., leadership, authority structures, reward systems, codes and policies, decision-making processes, ethical norms, peer behaviour, etc.) that can support either ethical or unethical behaviour in an organization.

\section{Ethical Behaviour and Organizational Citizenship Behaviour (OCB)}

An examination of the two constructs indicates clear differences. Ethics derives from the Greek word ethnos, which means character or custom (Solomon, 1984). According to Solomon (1984), the etymology of the word suggests that its fundamental concerns are with individual character, including what it means to be a good person, and the social rules of right and wrong (morality), which govern one's conduct (Shaw, 1999). There is neither a universally accepted definition of ethics nor a standard measure that allows an individual or event to be uniformly judged as ethical or unethical. Two individuals judged by many as highly ethical may have divergent views on such issues as capital punishment, abortion, affirmative action, layoffs, plant closings, environmental issues, or discrimination (Ferrell, Fradrich \& Farrell, 2000).

\section{Ethical Behaviour and Deviant Workplace Behaviour (DWB)}

Ethical and deviant workplace behaviour as now becoming a prevalent problem in business as DWB has become a vital concern. Researchers such as Ashkanasy, Windosor, and Trevino (2006) report that 75 percent of employees have stolen from their employers at least once. Twenty percent of companies participating in an American Management Association survey reported they had experienced workplace violence and 33 percent of a population of 500 human resource professionals reported threats of violence in their workplace (Romano, 1994). It is estimated that between 33 and 75 percent of all employees have engaged in other aggressive behaviours such as theft, fraud, vandalism, and sabotage (Harper, 1990 in Anyim, Obisi \& Aliyu, 2018).

\section{Reasons for Unethical Behaviour}

Presence of counter norms and the reasons organizations often reward behaviour that is counter to what is generally accepted as ethical; these are referred to as counter norms. For example, being open and honest is a quality that most would agree is desirable. However, organizations often find it beneficial to be secretive and deceitful. Similarly, organizations tend to reward individuals who pass the buck, instead of taking responsibility for their actions (Sims, 1992 in Baker, Hunt \& Andrew 2006). A possible reason for these counter norms is referred to as the bottom-line mentality. This mentality encourages financial success at the expense of other values. It promotes short-term solutions that are financially sound, despite the fact that they cause problems for others within the organization or the organization as a whole (Baker et al. 2006; Bennet \& Robbinson, 2003). The mentality encourages employees to 
view ethics as an obstacle to profit. Instead of relying on legitimate morals, individuals within organizations are concerned with whether they can manage to appear ethical.

A possible result of a counter norm within the DWB context would be the effect ratio. This occurs when less dramatic, but still deviant, behaviour occurs covertly in the workplace. The aggressor generally seeks behaviours that are effective in harming the victim (whether the victim is the organization or another individual) while incurring as little danger to themselves as possible. This ratio is influenced by a few factors. First, the aggressor is often in repeated contact with the victim resulting in the reasonable expectation to run into the victim again and again over periods of time. Secondly, due to the surrounding workforce, there is a built-in audience of highly-interested observers who are likely to notice overt behaviours. This fact often serves to reduce aggression, especially when the audience is expected to disapprove of such behaviour (Baron and Neuman, 1998 in Choi, Dixon \& Jung, 2014). These factors also produce another frustrating factor for the victim: uncertainty. Potential aggressors tend to strongly prefer forms of aggression in work settings that allow them to disguise their identity and leave the victim, wondering as to whether the action was intentional (Lawrence \& Robbinson, 2017).

\section{Attributions Theory}

Attribution theory was proposed by Heider (1958) on the ground that people have an innate need to understand and control their environments. According to him, individuals function as naïve psychologists, developing causal explanations for their own and other's behaviour, based on a combination of external information, and internal beliefs and motives. These explanations influence expectations, emotions, and subsequent behaviour. Heider (1958) clarified attributions theory on three (3) essential dimensions such as locus of causality, controllability, and stability.

Locus of causality refers to whether the cause of an event is internal or external to a person. Controllability is whether a person has control over an internally caused event. Some internal causes, such as lack of motivation, are seen as controllable, whereas others, such as lack of required skill to perform a task, are seen as uncontrollable. Stability is whether the cause is something permanent in a person or the environment, or whether it is a temporary condition. Lack of ability is likely seen as a permanent cause of poor performance, whereas being ill would be likely seen as something temporary.

Studies revealed that motivation theories suggest the applicability of attributions theory to emotions that lead to behaviors. For interpersonal situations, anger mediates the relationship between controllable attributions and aggression, whereas sympathy mediates the relationship between uncontrollability and helping will elicit an attributional process. If the need for help is seen as internal and controllable, it is likely that the reaction will be anger and unethical behavior. For intrapersonal situations, controllability with an internal locus of 
causality will lead an individual to experience guilt, which may lead to greater efforts.

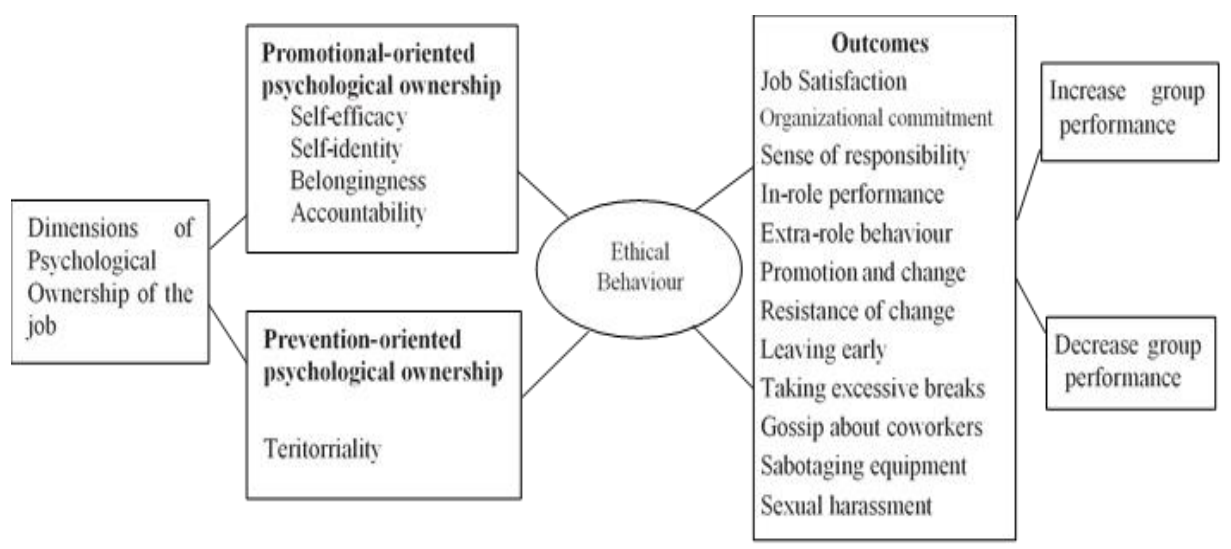

Figure 01: Model of the Study

Source: Authors, 2018

\section{Research Methodology}

The survey research method was employed, this is because survey research can be used in determining the distribution and interrelationships among sociological and psychological variables such as opinion and attitudes of respondents (Farrell, et al, 2000). The legitimate population of this study is all academic staff working in selected Federal universities in Nigeria. As of 2017, when this study commenced, there were forty (40) Federal universities (see appendix) spread across the six geo-political zones of the Nigerian Federation (NUC, 2017). The six geo-political zones are North Central, North East, North West, South East, South West, and South-South. Federal universities were chosen for the study because they are the largest government-funded tertiary institutions in Nigeria

The distribution of the population and sample of the study are presented in Table 02 below. 
Table 02: Selection of a Proportional Sample from Population of the Study

\begin{tabular}{|c|c|c|c|c|c|c|c|}
\hline :ّ̊̆ & 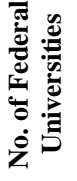 & 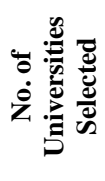 & : & 泀 & 。ำ & 芯 & 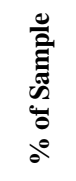 \\
\hline \multirow{2}{*}{$\begin{array}{l}\text { North } \\
\text { Central }\end{array}$} & \multirow{2}{*}{7} & \multirow{2}{*}{2} & $\begin{array}{l}\text { University of } \\
\text { Ilorin }\end{array}$ & 1018 & $13 \%$ & 51 & $13 \%$ \\
\hline & & & $\begin{array}{l}\text { Federal } \\
\text { University, } \\
\text { Lokoja }\end{array}$ & 118 & $2 \%$ & 6 & $2 \%$ \\
\hline \multirow{2}{*}{$\begin{array}{l}\text { North } \\
\text { East }\end{array}$} & \multirow[b]{2}{*}{6} & \multirow[b]{2}{*}{2} & $\begin{array}{l}\text { University of } \\
\text { Maiduguri }\end{array}$ & 886 & $11 \%$ & 44 & $11 \%$ \\
\hline & & & $\begin{array}{l}\text { Federal } \\
\text { University } \\
\text { Gashua }\end{array}$ & 125 & $2 \%$ & 6 & $2 \%$ \\
\hline \multirow{2}{*}{$\begin{array}{l}\text { North } \\
\text { West }\end{array}$} & \multirow{2}{*}{9} & \multirow{2}{*}{2} & $\begin{array}{l}\text { Bayero } \\
\text { University, } \\
\text { Kano }\end{array}$ & 834 & $10 \%$ & 42 & $10 \%$ \\
\hline & & & $\begin{array}{l}\text { Federal } \\
\text { University, } \\
\text { Birnin Kebbi }\end{array}$ & 208 & $3 \%$ & 10 & $3 \%$ \\
\hline \multirow{2}{*}{$\begin{array}{l}\text { South } \\
\text { East }\end{array}$} & \multirow{2}{*}{5} & \multirow{2}{*}{2} & $\begin{array}{l}\text { University of } \\
\text { Nigeria, } \\
\text { Nsukka }\end{array}$ & 1511 & $19 \%$ & 75 & $19 \%$ \\
\hline & & & $\begin{array}{l}\text { Federal } \\
\text { University, } \\
\text { Ndifu-Alike }\end{array}$ & 189 & $2 \%$ & 9 & $2 \%$ \\
\hline \multirow{2}{*}{$\begin{array}{l}\text { South } \\
\text { South }\end{array}$} & \multirow{2}{*}{6} & \multirow{2}{*}{2} & $\begin{array}{l}\text { University of } \\
\text { Port- } \\
\text { Harcourt }\end{array}$ & 1098 & $14 \%$ & 55 & $14 \%$ \\
\hline & & & $\begin{array}{l}\text { Federal } \\
\text { University, } \\
\text { Otuoke }\end{array}$ & 187 & $2 \%$ & 9 & $2 \%$ \\
\hline \multirow{3}{*}{$\begin{array}{l}\text { South } \\
\text { West }\end{array}$} & \multirow{2}{*}{7} & \multirow{2}{*}{2} & $\begin{array}{l}\text { University of } \\
\text { Lagos, } \\
\text { Akoka }\end{array}$ & 1504 & $19 \%$ & 75 & $19 \%$ \\
\hline & & & $\begin{array}{l}\text { Federal } \\
\text { University, } \\
\text { Oye-Ekiti }\end{array}$ & 203 & $3 \%$ & 10 & $3 \%$ \\
\hline & 40 & 12 & & 7881 & $100 \%$ & 392 & $100 \%$ \\
\hline
\end{tabular}

Sources: Author's Computation, 2017; NUC and Joint Admissions and Matriculation Board, U.T.M.E Brochure, 2017; National Bureau of Statistic (NBS), 2017

Firstly, the universities were grouped into the existing six geo-political zones in Nigeria. Secondly, two universities (one from old conventional and one from recently established universities) were randomly selected from each of the six geo-political zones. The selection resulted in twelve (12) 
universities. The population of the study stood at 7,881 of only academic staff members. Third, a proportional sample size of academics in each of the universities was selected, giving a total of 392 an equivalent of $5 \%$ of the legitimate population.

Upon completion of data collection or analysis, a combination of both descriptive and inferential statistics was employed as methods of data analysis. Preliminary tests were conducted to determine the response rate, reliability, and validity of the study constructs. Bivariate correlation and multiple regression analysis were employed to analyze relationships among construct variables. The mediated model of this study was tested using the hierarchical regression analysis.

\section{Hypotheses Testing}

H1: Employee's self-efficacy has no relationship with individual ethical behavior in the selected Nigerian public universities.

Table 03: Model Summary

\begin{tabular}{|c|c|c|c|c|}
\hline Model & R & R Square & $\begin{array}{c}\text { Adjusted R } \\
\text { Square }\end{array}$ & $\begin{array}{c}\text { Std. Error of the } \\
\text { Estimate }\end{array}$ \\
\hline 1 & $.817^{\mathrm{a}}$ & .668 & .660 & .28536 \\
\hline
\end{tabular}

a. Predictors: (Constant), ESE, IEB

Source: Survey Data, 2018

The result in the model summary Table 03 indicates that employee's selfefficacy and individual ethical behaviour variables were jointly explained at $66.8 \%$ variance of university' employees' behaviour, while the remaining $33.2 \%$ could be due to the effect of extraneous variables not accounted by the model. The adjusted R-square (0.660) which is a value just so close to R-square (0.668) depicts the fact that if the model is sampled from the population rather than the sample, it will account for a negligible difference of $0.8 \%$ variance in the outcome. Therefore, model fitness is good. $\mathrm{R}=0.817$ implies that the relationship between employees' self-efficacy (ESE) and individual ethical behaviour (IEB is high because the correlation coefficient is close to 1 . 
Table 04: ANOVA ${ }^{\mathrm{a}}$

\begin{tabular}{|c|c|c|c|c|c|c|}
\hline \multicolumn{2}{|l|}{ Model } & $\begin{array}{c}\text { Sum of } \\
\text { Squares }\end{array}$ & Df & $\begin{array}{c}\text { Mean } \\
\text { Square }\end{array}$ & F & Sig. \\
\hline \multirow{2}{*}{1} & Regression & 13.579 & 2 & 6.789 & 83.375 & $.000^{\mathrm{b}}$ \\
\cline { 2 - 7 } & Residual & 6.759 & 83 & .081 & & \\
\cline { 2 - 7 } & Total & 20.337 & 85 & & & \\
\hline
\end{tabular}

a. Dependent Variable: Bank's performance

b. Predictors: (Constant), ESE, IEB

Source: Survey Data, 2018

Table 04 presents the overall diagnostic test of significance using Analysis of Variance (ANOVA) between joint relations of employee's self-efficacy, individual ethical behaviour of University staff. The ANOVA results for regression coefficients indicate that the significance of the $\mathrm{F}=83.375>\mathrm{F}$ table $=3.84$ at a degree of freedom of $(2$, 83 ); i.e. $\mathrm{P}$-value $=0.00$ is less than 0.05 .
This indicates that the employees' selfefficacy and individual ethical behaviour significantly predicts the university staff behaviour (meaning it is a good fit for the model). Therefore, a significant relationship between joints effect of employee's selfefficacy and individual ethical behaviour of university's staff exists at 95\% confidence level.

Table 05: Regression Coefficients ${ }^{\mathrm{a}}$

\begin{tabular}{|c|c|c|c|c|c|c|}
\hline \multirow{2}{*}{ Model } & \multicolumn{2}{|c|}{$\begin{array}{c}\text { Unstandardized } \\
\text { Coefficients }\end{array}$} & $\begin{array}{c}\text { Standardized } \\
\text { Coefficients }\end{array}$ & \multirow{2}{*}{ Sig. } & \\
\cline { 3 - 7 } & B & $\begin{array}{c}\text { Std. } \\
\text { Error }\end{array}$ & Beta & & \\
\hline \multirow{3}{*}{1} & (Constant) & .264 & .082 & & 3.219 & .000 \\
\cline { 2 - 7 } & PSYC & .115 & .049 & .291 & 2.345 & .021 \\
\cline { 2 - 7 } & DWB & -.216 & .049 & -.553 & -4.451 & .000 \\
\hline
\end{tabular}

a. Dependent Variable: Lecturer's behaviour

Source: Survey Data, 2018

From regression Table 5, it can be deduced that individual ethical behaviour has the least beta $(\beta=$ 0.216 ) and this implies that individual ethical behaviour has a negative influence on university's staff in the selected areas. $21.6 \%$ decrease in the ethical behaviour of the staff is caused by an increase in individual ethical behaviour by $1 \%$. Employee's selfefficacy with $(\beta=0.115)$ has a direct positive effect on ethical behaviour of university lecturers, and it significantly affects how he/she behaviour in an organization by $11.5 \%$ at $5 \%$ level. This result implies that both employee's self-efficacy and individual ethical behaviour has a significant impact on bank's performance, which the incorporated results of model summary in table 3 and ANOVA table 4 failed to indicate the 
direction of the impact because of the insensitivity of statistical power. The constant of regression further in the prediction that if $\mathrm{ESE}=\mathrm{IEB}=0$, then the universities behave ethically by $26.4 \%$ and it is significant at 5\% level. Therefore, it seems the removal of employee's self-efficacy and individual ethical behavior can be used for inference. Hence, the null hypothesis is rejected, and the alternative hypothesis is accepted by posited that Employee's self-efficacy have no relationship with the individual ethical behavior of lecturers in the selected Nigerian public universities at $5 \%$ level of significance.

$\mathbf{H}_{2}$ : There is no relationship between employee sense of belonging and benevolent ethical behavior of employees in selected Nigerian public universities.

\section{Table 06: Pearson Correlations matrix indicating the overall significant} relationship between the dimension of psychological ownership (Employee selfefficacy, employee sense of belonging, Territoriality) and deviant work behaviour (DWB)

\begin{tabular}{|c|c|c|c|c|c|}
\hline & & DWB & $\begin{array}{c}\text { Employee } \\
\text { Self- } \\
\text { efficacy }\end{array}$ & ESB & Terr. \\
\hline \multirow{3}{*}{ DWB } & $\begin{array}{l}\text { Pearson } \\
\text { Correlation }\end{array}$ & 1 & $-.767^{* *}$ & $-.821^{* *}$ & $-.857^{* *}$ \\
\hline & Sig. (2-tailed) & & .000 & .000 & .000 \\
\hline & $\mathrm{N}$ & 86 & 86 & 86 & 86 \\
\hline \multirow{3}{*}{$\begin{array}{l}\text { Employee self- } \\
\text { efficacy }\end{array}$} & $\begin{array}{l}\text { Pearson } \\
\text { Correlation }\end{array}$ & $-.767^{* *}$ & 1 & $.916^{* *}$ & $.930^{* *}$ \\
\hline & Sig. (2-tailed) & .000 & & .000 & .000 \\
\hline & $\mathrm{N}$ & 86 & 86 & 86 & 86 \\
\hline \multirow{3}{*}{ ESB } & $\begin{array}{l}\text { Pearson } \\
\text { Correlation }\end{array}$ & $-.821^{* *}$ & $.916^{* *}$ & 1 & $.893^{* *}$ \\
\hline & Sig. (2-tailed) & .000 & .000 & & .000 \\
\hline & $\mathrm{N}$ & 86 & 86 & 86 & 86 \\
\hline \multirow{3}{*}{ Territoriality } & $\begin{array}{l}\text { Pearson } \\
\text { Correlation }\end{array}$ & $-.857^{* *}$ & $.930^{* *}$ & $.893^{* *}$ & 1 \\
\hline & Sig. (2-tailed) & .000 & .000 & .000 & \\
\hline & $\mathrm{N}$ & 86 & 86 & 86 & 86 \\
\hline
\end{tabular}

**. Correlation is significant at the 0.05 level (2-tailed)

Source: Survey Data, 2018

Table 06 indicates the correlation coefficients of all dimensions of psychological ownership which include employee sense of belonging ($0.821)$ and territoriality $(-0.857)$ to have jointly and individually related with benevolent ethical behaviour (BEB). This implies all dimensions have inverse relationship with deviant work behaviour and that the increases in each of the dimension of psychological ownership (sense of belonging and territoriality) decrease the BEB. In contrast, the decrease in psychological ownership dimensions (such as a sense of belonging and territoriality) will increase benevolent ethical behaviour at $5 \%$ level of 
significance. This result supported the social exchange theory by Blau (1964) that behaviours shaped by perceptions and attitudes of psychological ownership through which employee work behaviours reflected in selfefficiency, teamwork spirit and territoriality of the selected universities

\section{Discussion}

From hypothesis 1, the finding revealed that employee's self-efficacy and individual ethical behaviour have a significant impact on how lecturer in tertiary universities behave. Individual ethical behaviour (IEB) has the least regression parameter $(\beta=-0.216)$, which implies that $21.6 \%$ decrease in university's staff behaviour is caused by $1 \%$ increase in individual ethical behaviour. Employee's self-efficacy (ESE) with $(\beta=0.115)$ has a direct positive effect on how university' lecturers behave, and the result posited that employee's self-efficacy significantly encourage ethical behaviour among university staff by $11.5 \%$ and it is equally significant at $5 \%$ level. Therefore, the null hypothesis was rejected, and the alternative hypothesis was accepted by posited that there is the significant negative impact of employee's selfefficacy and individual ethical behaviour on the academic staff of universities at $5 \%$ level of significance.

Finding in hypothesis 2 indicate the correlation coefficients of all dimensions of psychological ownership which include employee sense of belonging $(-0.821)$ and territoriality $(-0.857)$ were jointly and individually related with benevolent ethical behaviour (BEB). This implies as found in this test. Therefore, the null hypothesis 2 is rejected, and alternate hypothesis is accepted by posited that there is a relationship between employee sense of belonging and benevolent ethical behaviour of employees in selected Nigerian public universities at $5 \%$ level of significance.

all dimensions have an inverse relationship with $\mathrm{BEB}$ and that the increase in each of the dimension of psychological ownership (such as employee sense of belonging and territoriality) which decrease the BEB. In contrast, the decrease in psychological ownership dimensions will increase BEB at 5\% level of significance. This result supported the social exchange theory by Blau (1964) that behaviours shaped by perceptions and attitudes of psychological ownership through which employee work behaviours reflected in selfefficiency, teamwork spirit and territoriality for ethical behaviour of the academic staff of universities as found in this test. Therefore, the null hypothesis 2 was equally rejected, and the alternate hypothesis was accepted by posited that there is a relationship between employee sense of belonging and benevolent ethical behaviour of employees in selected Nigerian public universities at $5 \%$ level of significance.

\section{Conclusion and Recommendations}

The study discovered that the ethical behaviours had influenced academics in different ways showing a tendency for self-efficacy and a sense of belonging. Unfortunately, the tendency for academics' self-efficacy 
outweighed that of sense of belongingness. This can fulfil essential human motivations and needs to reduce deviant behavior in public universities. Employees having a sense of ownership with the organization are less likely to deviate from work norms and values. The study's theoretical implication in the sense that the findings of the study significantly contribute to advancing the body of knowledge of psychological ownership and ethical behavior. The practical implications have changed the focus from employees to employer decisionmaking. It does so by using attribution theory for analyzing and explaining such a decision. The study recommends that:

- Universities should increase their level of compliance with ethical standard behavior.

- Universities should establish policies to prevent an increase in unethical behavior among academics.

- Universities should provide academics with the necessary resources and incentives. This will increase academics' organizational citizenship

behavior and reduce the tendency for deviant workplace behavior in public universities.

- The academics who uphold ethical behavior should be encouraged to sustain their good behavior.

\section{Limitation and Suggestions for Further Studies}

There is a need for additional studies that include non-academics, likewise a wider coverage of universities in order to investigate more specifically how other non-academics perceive their breach of the psychological contract compared to academics' counterpart. This will show how the relationships between psychological contract violation and discretionary behavior of non-academics. Despite of some limitations of the study, the results offered support to the theoretical propositions, key objectives, answered research questions, and provide gaps for future research on the area of breach of psychological contracts and discretionary behavior.

\section{References}

Appelbaum, S.H., Deguire, K.J. \& Lay, M. (2017). The relationship of ethical climate to deviant workplace behaviour. Emerald Group Publishing Limited, 5(4), 4355 .

Ashkanasy, N.M., Windsor, C.A., \& Treviño, L.K. (2006). Bad apples in bad barrels revisited: Personal factors and organizational rewards as determinants of managerial ethical decision-making. Business Ethics Quarterly, 16(1), 449-474.

Avey, J.B., Avolio, B.J., Crossley, C.D., \& Luthans, F. (2009). Psychological ownership: Theoretical extensions, measurement, and relation to work outcomes. Journal of Organizational Behaviour, 30(1), 173-191. 
Baker, T.L., Hunt, T.G. \& Andrews, M.C. (2006). Promoting ethical behaviour and organizational citizenship behaviours: The influence of corporate ethical values. Journal of Business Research, 59(1), 849-857.

Bennett, R.J. \& Robinson, S.L. (2003). The past, present and future of workplace deviance research, in Greenberg, J. (Ed.), Organizational Behaviour: The State of the Science, (2nd ed.), Erlbaum, Mahwah, New Jersey: Pearson Education Ltd.

Bernstein, P. (1979). Workplace democratization: Its internal dynamics. New Brunswick, New Jersey: Transaction Books Limited

Brown, M.E. \& Treviño, L.K. (2006). Ethical leadership: A review and future directions. The Leadership Quarterly, 17(1) 595-616.

Choi, N.H., Dixon, A.L., \& Jung, J.M. (2014). Dysfunctional behaviour among sales representatives: The effect of supervisor trust, participation, and information controls. Journal of Personal Selling and Sales Management, 24(1), 181-193.

Ferrell, O.C., Fraedrich, J. \& Ferrell, L. (2000). Business ethics. New York: Houghton Mifflin Inc.

Fombrun, C. \& Foss, C. (2004). Business ethics: Corporate responses to scandal. Corporate Reputation Review, 7(3), 284-288

Furby, L. (1991). Understanding the psychology of possession and ownership: A personal memoir and an appraisal of our progress. Journal of Social Behaviour and Personality, 6(6), 457-463.

Hou, S. T.; Hsu, M. Y. \& Wu, S. H. (2009). Psychological ownership and franchise growth: An empirical study of a Taiwanese taxi franchise. International Journal of Entrepreneurial Behaviour \&Research, 15(5), 415-435.

Kark, R., \& Van Dijk, D. (2007). Motivation to lead, motivation to follow: The role of the self-regulatory focus in leadership processes. Academy of Management Review, 32(2), 500-528.

Kidder, R. M. (2015). Moral courage, digital distrust: Ethics in a troubled world. Business and Society Review, 110(4), 485-505.

Lawrence, T.B. \& Robinson, S.L. (2017). Ain't misbehaving: workplace deviance as organizational resistance. Journal of Management, 33(3), 378-394.

Leung, A.S. (2008). Matching ethical work climate to in-role and extra-role behaviours in a collectivist work setting. Journal of Business Ethics, 79(2), 4355

Liberman, N., Idson, L.C, Camacho, C.J., \& Higgins, T.E. (1999). Promotion and prevention choices between stability and change. Journal of Personality and Social Psychology, 77(6), 1135-1145. 
Mayhew, M. G., Ashkanasy, N. M., Bramble, T., \& Gardner, J. (2007). A study of the antecedents and consequences of psychological ownership in organizational settings. The Journal of Social Psychology, 147(5), 477-500.

Mendonca, M. (2001). Preparing for ethical leadership in organizations. Canadian Journal of Administrative Sciences, 18(4), 266-276.

Mustapha, M., Martin, L. \& Hughes, M. (2016). Psychological ownership, job satisfaction, and middle manager entrepreneurial behaviour. Journal of Leadership \& Organizational Studies, 23(3), 272-287

Pierce, J.L., Jussila, I., \& Cummings, A. (2009). Psychological ownership within the job design context: Revision of the job characteristics model. Journal of Organizational Behaviour, 30(1), 477-496.

Pierce, J.L., Kostova, T., \& Dirks, K.T. (2003). The state of psychological ownership: Integrating and extending a century of research. Review of General Psychology, 7(1), 84-107.

Pierce, J.L., O'Driscoll, M.P., \& Coghlan, A.M. (2004). Work environment structure and psychological ownership: The mediating effects of control. Journal of Social Psychology, 144(5), 507-534.

Pratt, M.G., \& Dutton, J.E. (2000). Owning up or opting out: The role of identities and ambivalence in issue ownership. In Ashkanasy, N.M., Härtel, C.E. \& Zerbe, W.J. (Eds), Emotions in the workplace: Research, theory, and practice. Westport CT: Quorum Books/Greenwood

Samaila, M. (2015). Assessment of ethical and legal issues for public relations practitioners in Nigeria. Ilorin Journal of Marketing, 1(1), 226-235.

Shaw, W.H. (1999). Business ethics. Belmont. Canada: Wadsworth Publishers

Solomon, R.C. (1984). Morality and the good life. New York: McGraw-Hill Inc.

Tenbrunsel, A.E., Smith-Crowe, K., \& Umphress, E. (2003). Building houses on rocks: The role of the ethical infrastructure in organizations. Social Justice Research, 16(1), 285-307.

The Scholar. (2011). Employers assessment of graduate in the market place. Abuja, Nigeria: A publication of Academic Staff Union of Universities

Treviño, L.K., \& Nelson, K.A. (2007). Managing business ethics: Straight talk about how to do it right (4th Ed.). New York: Wiley \& Son Inc.

Treviño, L.K., Brown, M., \& Hartman, L.P. (2003). A qualitative investigation of perceived executive ethical leadership: Perceptions from inside and outside the executive suite. Human Relations, 55(1), 5-37. 
Treviño, L.K., Butterfield, K.D., \& Mcabe, D.M. (1998). The ethical context in organizations: Influences on employee attitudes and behaviours. Business Ethics Quarterly, 8(1), 447-476

Treviño, L.K., Hartman, L.P., \& Brown, M. (2000). Moral person and moral manager: How executives develop a reputation for ethical leadership. California Management Review, 42(1), 128-142

Treviño, L.K., Weaver, G.R., Gibson, D.G., \& Toffler, B.L. (1999). Managing ethics and legal compliance: What hurts and what works. California Management Review, 41(1), 131-151.

VandeWalle, D., Van Dyne, L., \& Kostova, T. (1995). Psychological ownership: An empirical examination of its consequences. Group and Organization Management, 20(2), 210-226.

Vardi, Y., \& Weitz, E. (2013). Misbehaviour in organizations: Theory, research, and management. Mahwah, New Jersey: Lawrence Erlbaum Associates, Inc

Victor, B. \& Cullen, J.B. (1988). The organizational bases of ethical work climates. Administrative Science Quarterly, 33(1), 101-125.

Wagner, S.H., Parker, C.P., \& Christianson, N.D. (2003). Employees that think and act like owners: Effects of ownership beliefs and behaviours on organizational effectiveness. Personnel Psychology, 56(1), 847-871. 